\title{
PERBANDINGAN PILL BOX DAN MEDICATION CHART DALAM MENINGKATKAN KEPATUHAN DAN OUTCOME KLINIK GERIATRI KOTA BATAM
}

\author{
COMPARATIVE PILL BOX AND MEDICATION CHART ON THE LEVELS COMPLIANCE AND \\ CLINICAL OUTCOME IN EDERLY PATIENTS AT BATAM
}

\author{
Suci Fitriani Sammulia, Fita Rahmawati, Tri Murti Andayani \\ Fakultas Farmasi, Universitas Gadjah Mada Yogyakarta
}

\begin{abstract}
ABSTRAK
Banyaknya obat yang dikonsumsi oleh pasien geriatri dengan penyakit kronis meningkatkan penurunan kepatuhan. Ada beberapa cara dalam meningkatkan kepatuhan diantaranya dengan menggunakan Pill box dan Medication reminder chart. Penelitian ini bertujuan untuk mengetahui perbandingan efektifitas penggunaan Pill box dengan Medication reminder chart dalam meningkatkan kepatuhan pasien geriatri dengan hipertensi di Kota Batam. Rancangan Penelitian ini adalah studi experimental; Randomized Controlled Trial dengan desain penelitian pre test dan post test control group. Pengambilan sampel pada penelitian ini dilakukan dengan teknik random alokasi sampling. Pasien akan dikelompokkan menjadi dua kelompok subjek yang berbeda, yaitu kelompok yang mendapat intervensi berupa Pill box dan Medication reminder chart. Data dikumpulkan secara prospektif sesuai dengan kriteria inklusi padap asien geritri rawat jalan, dengan diagnosa penyakit hipertensi di dua rumah sakit Kota Batam, penelitian dilakukan pada bulan Januari sampai April 2016. Pengukuran tingkat kepatuhan menggunakan kuesioner MMAS-8 dan pill count dan outcome klinik pasien diukur dengan melihat tekanan darah sistolik dan diastolik yang disesuaikan dengan diagnosa dokter yang tertera di rekam medik. Pengukuran dilakukan sebelum dan sesudah perlakuan. Data dianalisis secara statistik menggunakan deskripitif, uji bivariat. Hasil penelitian ini menunjukkan bahwa Pill box dapat meningkatkan kepatuhan $(P=0,000)$ dan menurunkan tekanan darah sistolik dan diastolik secara signifikan $(P=0,000$ dan $P=0,002)$, sedangkan pada Medication reminder chart hanya efektif dalam meningkatkan kepatuhan $(P=0,000)$. Terdapat perbedaan yang signifikan antara Pill box dan Medication reminder chart dalam meningkatkan kepatuhan $(P=0,008)$ dan pada penurunan tekanan darah sistolik dan $\operatorname{diastolik}(P=0,006$ dan $P=0,016)$.
\end{abstract}

Kata Kunci: Pill box, Medication reminder chart, Geriatri, Hipertensi, Kota Batam

\section{ABSTRACT}

The large amount of drugs consumed by geriatric patients with chronic illness increase a decline in obedience. There are several means to increase obedience such as employing Medication Reminder Chart and Pill Box. This research aims to discover the comparison of effectiveness in the application of Pill Box and Medication Reminder Chart in improving obedience among geriatric patients with hypertension in Batam. The design of this research is experimental study, by utilizing Randomized Controlled Trial with pre- and post-test control group. The sample obtained for this research is conducted by applying Random Allocation technique. Patients were grouped into two different groups which will receive the intervention of Pill Box and Medication Reminder Chart. The data were collected prospectively based on inclusion criteria towards geriatric outpatients with hypertension diagnosis in two hospitals in Batam, a research which was conducted from January to April 2016.The measurement of obedience level uses MMA-8 questionnaire and pill count. The clinical outcome of patients was measured by observing systolic and diastolic blood pressure based on doctor's diagnosis on the medical chart. The measurement was preceded before and after treatment. The data were analyzed statistically, descriptively using bivariate analysis. The result demonstrates that Pill Box can increase obedience $(P=0,000)$ and significantly decrease systolic and diastolic blood pressure $(P=0,000 \operatorname{dan} P=0,002)$ whereas Medication Reminder Chart is only effective in increasing obedience $(P=0,000)$. There is a significant difference between Pill Box and Medication Reminder Chart in increasing obedience $(P=0,008)$ and decreasing systolic and diastolic blood pressure $(P=0,006 \operatorname{dan} P=0,016)$.

Keywords: Pill box, Medication reminder chart, Geriatric, Hypertension, Batam

\section{PENDAHULUAN}

Dalam beberapa dekade terakhir diseluruh dunia penduduk lanjut usia tumbuh dengan sangat cepat bahkan tercepat dibanding kelompok usia lainnya (United Nations, 2007).

Peningkatan jumlah lansia tersebut, berdampak pada munculnya masalah kesehatan,

\section{Korespondensi}

\section{Suci Fitriani Sammulia}

Magister Farmasi Klinik Universitas Gadjah Mada

virgin.sammulia22@gmail.com yang terjadi pada lansia berupa masalah fisik, biologi, maupun psikososial (Watson, 2003; Hutapea, 2005). Kepatuhan biasanya menjadi masalah pada pasien dengan penyakit kronis yang membutuhkan modifikasi gaya hidup dan terapi jangka panjang. Ketidakpatuhan pada pasien hipertensi secara potensial dapat meningkatkan morbilitas, mortalitas dan biaya perawatan (Ogedegbe et al., 2009; Fung et al., 2007).

Ketidak patuhan menjadi salah satu hambatan / barrier dalam mencapai kesuksesan 
pengobatan terutama penyakit kronis (Laubscher et al., 2009). Ada beberapa jenis intervensi yang dapat dilakukan oleh farmasis dalam meningkatkan kepatuhan pasien (Dulmen et al., 2007). Salah satu intervensi yang dapat diberikan oleh farmasis dalam meningkatkan kepatuhan dengan menggunakan medication reminder chart, medication reminder chart adalah sebuah alat yang dapat membantu untuk mengatasi pasien lupa minum obat, dengan cara memberikan tanda pada kolom yang tersedia pada medication reminder chart setelah meminum obatnya (Gabriel et al., 1977; Conn et al., 2009). Medication reminder chart yang didesign oleh peneliti dapat di gunakan oleh pasien sebagai identitas pengobatan pasien yang dapat dibawah pasien dalam berpergian, karena pada medication reminder chart berisi riwayat pengobatan pasien serta alergi pengobatan pasien, sehingga medication reminder chart ini dapat membantu dokter dalam meresepkan pengobatan untuk pasien tersebut.

Selain medication reminder chart, pada penelitin ini juga menggunakan Pill box, Pill box juga dapat meningkatkan kepatuhan pasien dalam menjalankan penggobatannya, Pill box membantu pasien untuk memilah dan mengatur obat ke dosis tunggal sesuai dengan waktu dan hari dalam seminggu (Petersen et al., 2007).

Pada penelitian ini identifikasi kepatuhan pasien dilakukan menggunakan instrument kuesioner Morisky Medication Adherence Scale (MMAS-8) yang dikembangkan oleh Morisky et al., (2009). Kepatuhan pasien juga dievaluasi melalui jumlah sisa obat (pill count) saat pasien kontrol pada pemeriksan periode berikutnya (Lee et al., 2007).

Berdasarkan hasil wawancara pada observasi awal yang dilakukan sebelum penelitian dimulai pada bulan Desember 2015, diketahui bahwa pola penyakit geriatri rawat jalan di dua rumah sakit di Kota Batam terbanyak adalah hipertensi. Oleh karena itu perlu dilakukan upaya dalam peningkatan pengobatan. Upaya yang dapat dilakukan pada penelitian ini yaitu intervensi berupa pemberian pill box dan medication reminder chart dalam meningkatkan kepatuhan, khususnya pada pasien geriatri dengan hipertensi. Dua rumah sakit di Kota Batam yang dijadikan sebagai tempat penelitian merupakan sarana kesehatan dengan jumlah kunjungan pasien hipertensi yang cukup banyak akan tetapi peran farmasis untuk memberikan intervensi dalam meningkatkan kepatuhan belum berjalan. Penelitian ini bertujuan untuk mengetahui pengaruh penggunaan medication reminder chart dan Pill box dalam membantu pasien geriatri meningkatkan kepatuhan dan outcome klinik pada pasien geriatri dengan hipertendi di Kota Batam. Penelitian mengenai intervensi farmasis terhadap peningkatan kepatuhan dan outcome klinik pasien geriatri dengan hipertensi belum pernah di lakukan.

\section{METODE}

Penelitian ini dilaksanakan dengan rancangan studi experimental; Randomized Controlled Trial dengan desain penelitian pre-test dan post-test control group desisgn pada bulan Januari hingga April 2016 dua rumah sakit di Kota Batam Kepulauan Riau. Pengambilan sampel pada penelitian ini menggunakan teknik random alokasi sampling yaitu dengan cara memberi kode A untuk pill box dan B untuk medication reminder chart lalu diacak dengan menggunakan blok sekuen (kombinasi A-B) untuk menentukan pasien akan mendapatkan intervensi pill box atau medication reminder chart. Pengacakan sampel dilakukan dengan program komputer dengan menggunakan 6 blok kombinasi huruf A-B untuk antar kelompok yang disebut blok sekuen (sequence generation) (Kim et al., 2014). Data dikumpulkan secara prospektif pada subyek geriatri rawat jalan, dengan diagnosa penyakit hipertensi. Pengukuran tingkat kepatuhan dan outcome klinik subyek dilakukan sebelum dan sesudah perlakuan.

Proses pengundian dilakukan sebelum masa intervensi sehingga pengelompokan subyek tidak berdasarkan kehendak peneliti dan tanpa diketahui oleh subyek penelitian. Seluruh subyek dalam penelitian ini dapat mengikuti penelitian hingga akhir yaitu 30 hari, kemudian dilakukan pengukuran kepatuhan dengan wawancara menggunakan kuesioner 
MMAS-8 dan pill count. Pemilihan jarak waktu pelaksanaan pre test dan post test disesuaikan denga teori evaluasi yang menyatakan bahwa jarak antara pengukuran minimal 2 minggu untuk pengetahuan dan minimal 1 bulan untuk sikap dan perilakunya (Budiharto, 1999).

Populasi penelitian ini adalah subyek geriatri dengan penyakit hipertensi di Instalasi rawat jalan poli penyakit dalam di dua rumah sakit Kota Batam dimulai dari bulan Januari sampai bulan April 2016. Subyek penelitian ini adalah pasien geriatri dengan penyakit hipertensi yang memenuhi kriteria inklusi. Kriteria inklusi : pasien yang berusia $\geq 60$ tahun, pasien dengan penyakit hipertensi diinstalasi rawat jalan penyakit pada dua rumah sakit di Kota Batam, pasien menjalani terapi rutin di instalasi rawat jalan penyakit dalam di dua rumah sakit Kota Batam, pasien yang memiliki kepatuhan sedang dan rendah, dilihat dari skor MMAS-8, tekanan darah pasien baik dengan atau tanpa penyakit penyerta adalah $\geq 140 / 90$ $\mathrm{mmHg}$, Pasien belum pernah menggunakan Pill box dan Medication reminder chart, bersedia mengikuti penelitian dengan menandatangani informed consent. Kriteria eksklusi: pasien pikun. Sedangkan kriteria drop out adalah pasien yang tidak datang kontrol pada masa waktu yang ditentukan, pasien mengundurkan sendiri selama proses penelitian berjalan, pasien meninggal ditengah penelitian.

Pada penelitian ini perhitungan besaran sampel dilakukan dua kali yaitu besaran sampel untuk tekanan darah sistolik dan diastolik, besaran sampel yang digunakan adalah besaran sampel yang terbesar yaitu 47 per kelompok (biasanya ditambahan $20 \%$ untuk menghindari subyek penelitian yang drop out selama penelitian sehingga subyek yang harus diambil adalah $(47+20 \%=47+9=56$ orang per kelompok). Terbatasnya waktu penelitian sehingga pada penelitian ini hanya didapatkan 50 subyek perkelompok tanpa ada subyek yang drop out.

Analisis yang dilakukan pada penelitian ini analisis deskriptif yang digunakan untuk memperoleh gambaran distribusi frekuensi serta proporsi dari variabel yang diteliti, seperti karakteristik subyek penelitian sebelum dilakukan intervensi untuk memastikan bahwa kedua kelompok terdistribusi' secara normal/homogen sehingga dapat menghindari bias.

Analisis Bivariat : Uji Chi Square digunakan untuk untuk melihat perbedaan proporsi masing-masing variabel karakteristik antara kedua kelompok intervensi dan melihat pengaruh variabel penganggu terhadap kepatuhan dan tekanan darah sistolik maupun diastolik, Uji Kolmogorov - Smirnov digunakan untuk menguji normalitas data, Uji Fisher's digunakan sebagai alternatif jika data tidak memenuhi syarat untu dilakukan uji Chi-square, dengan syarat tabel $2 \times 2$, Uji Independent-sampel $t$ test dilakukan untuk membandingkan perubahan nilai skor MMAS sebelum intervensi antara kelompok pill box dan medication reminder chart, data yang terdistribusi normal, serta Uji Mann-Whitney dilakukan untuk membandingkan skor MMAS-8, tekanan darah sistolik dan tekanan darah sistolik setelah intervensi antara kelompok pill box dan medication reminder chart, digunakan untuk data yang tidak normal, serta sebagai alternatif jika tidak dapat diuji Fisher.

\section{HASIL DAN PEMBAHASAN}

Penelitian ini diikuti 100 subyek penelitian dengan pertimbangan kriteria inklusi dan ekslusi penelitian, yang terdiri atas 50 subyek pada kelompok subyek yang diberikan Pill box dan 50 subyek pada kelompok yang diberikan medication reminder chart. Pemberian pill box dan medication reminder chart sebagai alat bantu untuk mengingat minum obat.

Uji statistik pada penelitain ini dilakukan uji Chi-Square terhadap karakteristik subyek penelitian, yaitu variabel jenis kelamin, usia, stres, minum alkohol, merokok, penyakit penyerta dan pola peresepan serta karakteristik awal kepatuhan dan outcome klinik yang digunakan menghasilkan nilai $\mathrm{P}>0,05$ yang menunjukkan tidak terdapat perbedaan proporsi masing-masing variabel antara kelompok pill box dan medication reminder chart sebelum intervensi (Tabel I). 
Tabel I. Karakteristik Pasien Geriatri dengan Hipertensi

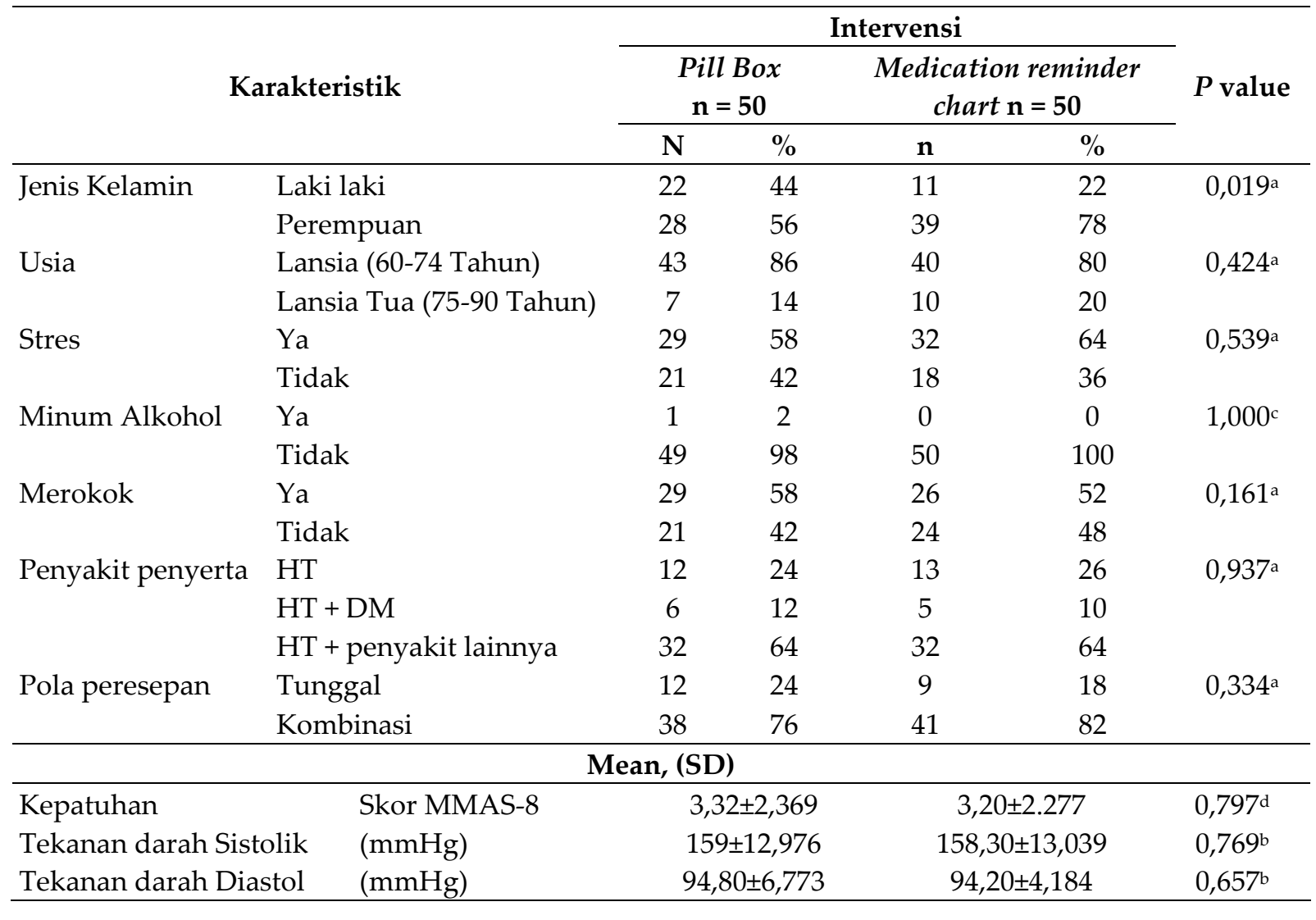

Keterangan : ${ }^{a}$ Hasil analisis statistik uji Chi-Square, ${ }^{b}$ Hasil Uji Mann-Whitney test, ${ }^{c}$ Hasil Uji Fisher's, $\quad{ }^{d}$ Hasil uji Independent Sampels Test

Menurut Singalingging (2011) rata-rata perempuan akan mengalami peningkatan resiko tekanan darah tinggi (hipertensi) setelah menopouse yaitu usia di atas 45 tahun. perempuan yang belum menopouse dilindungi oleh hormon estrogen yang berperan dalam meningkatkan kadar High Density Lipoprotein (HDL). Kadar kolesterol HDL yang tinggi merupakan faktor pelindung dalam mencegah terjadinya proses aterosklerosis Efek perlindungan estrogen dianggap sebagai penjelasan adanya imunitas wanita pada usia premenopause. Pada premenopause wanita mulai kehilangan sedikit demi sedikit hormon estrogen yang selama ini melindungi pembuluh darah dari kerusakan. proses ini terus berlanjut dimana hormon estrogen tersebut berubah kuantitasnya sesuai dengan umur wanita secara alami, yang umumnya mulai terjadi pada wanita umur 45-55 tahun (Kumar et al., 2005; Anggraini et al., 2009).

Pengaruh Pill box dan Medication reminder chart terhadap Kepatuhan

Berdasarkan klasifikasi tingkat kepatuhan (tinggi, sedang dan rendah), dan disesuaikan dengan kriteria inklusi tingkat kepatuhan yaitu bahwa subyek yang memiliki kepatuhan dibawah 8 yang artinya subyek penelitian yang memiliki tingkat kepatuhan sedang dan rendah. Pengukuran kepatuhan dengan menggunakan skor MMAS-8, maka dapat dilihat jumlah subyek penelitian Pill box dengan kategori kepatuhan rendah berkurang setelah intervensi Pill box dari $76 \%$ menjadi $12 \%$, dan subyek penelitian dengan kategori tinggi terjadi peningkatan menjadi $74 \%$, dan kategori sedang dari $24 \%$ berkurang menjadi $14 \%$. 
Tabel II. Skor MMAS-8, Tekanan Darah Sistolik dan Tekanan Darah Diastolik Sebelum dan Sesudah Intervensi

\begin{tabular}{lcccccc}
\hline \multirow{2}{*}{ Variabel } & \multicolumn{2}{c}{ Pill Box } & \multirow{2}{*}{ Pvalue } & \multicolumn{2}{c}{ Medication Reminder Chart } & \multirow{2}{*}{ P value } \\
\cline { 2 - 3 } & Pre Test & Post Test & & Pre Test & Post Test & \\
\hline MMAS-8 & 3,32 & 7,44 & 0,000 & 3,20 & 6,10 & 0,000 \\
TDS $\left(\mathrm{mmHg}^{2}\right.$ & 159 & 149 & 0,000 & 158,30 & 158,50 & 0,864 \\
TDD $\left(\mathrm{mmHg}_{-}\right.$ & 94,80 & 89,80 & 0,002 & 94,20 & 94,40 & 0,870 \\
\hline
\end{tabular}

Keterangan : Hasil Uji Statistik Wilcoxon, TDS=Tekanan Darah Sistolik, TDD=Tekanan Darah Diastolik.

Tabel III. Tingkat Kepatuhan Subyek Penelitian Berdasarkan Pill Count pada Pasien Geriatri dengan Hipertensi Post Test

\begin{tabular}{cccccc}
\hline \multirow{3}{*}{ Profil kepatuhan pasien } & \multicolumn{4}{c}{ Kelompok } & \\
\cline { 2 - 5 } & \multicolumn{3}{c}{ pill box } & \multicolumn{3}{c}{ medication reminder chart } & \multirow{2}{*}{ p value } \\
\cline { 2 - 5 } & $\mathbf{n}(\mathbf{5 0 )}$ & $\mathbf{\%}$ & $\mathbf{n}(\mathbf{5 0 )}$ & $\mathbf{\%}$ & \multirow{2}{*}{0,001} \\
\hline Patuh & 35 & 70 & 18 & 36 & \\
\hline Tidak patuh & 15 & 30 & 38 & 64 & \\
\hline
\end{tabular}

Keterangan : Hasil uji Mann-Whitney Test

Tabel IV. Rerata Perbandingan Efektifitas Pill Box dan medication reminder chart terhadap Rerata Peningkatan Skor MMAS-8, penurunan Tekanan Sistolik dan Diastolik

\begin{tabular}{lccc}
\hline \multirow{2}{*}{\multicolumn{1}{c}{ Variabel }} & \multicolumn{2}{c}{ Perubahan Nilai Rata-rata Setelah Intervensi } & \multirow{2}{*}{ P value } \\
\cline { 2 - 3 } & Pill Box & Medication Reminder Chart & \\
\hline Skor MMAS-8 & 4,16 & 2,90 & $0,008^{\mathrm{a}}$ \\
Tekanan darah sistolik & 10,00 & $-0,2$ & $0,006^{\mathrm{b}}$ \\
Tekanan darah diastolic & 5,00 & $-0,2$ & $0,015^{\mathrm{a}}$ \\
\hline
\end{tabular}

Keterangan : aHasil Uji Statistik Mann-Whitney Test, ${ }^{b}$ Hasil Uji Statistik Independent $t$ Test

Pada penggunaan medication reminder chart terdapat peningkatan kepatuhan 30\%, dan adanya penurunan jumlah subyek penelitian yang kepatuhan rendah dari $80 \%$ menjadi $46 \%$ serta pada subyek penelitian yang dikategorikan sedang meningkat dari $20 \%$ menjadi $24 \%$.

Skor MMAS-8 nilai rata-rata sebelum mendapatkan Pill box adalah 3,32 sedangkan setelah mendapatkan Pill box menjadi 7,44, adanya peningkatan kepatuhan dari peningkatan skor MMAS-8 sebesar 4,12. Dari uji Wilcoxon yang dilakukan maka didapatkan nilai $P=0,000$, dengan nilai $P<0,005$ maka dapat disimpulkan ada perbedaan yang bermakna pada kelompok Pill box terhadap kepatuhan sebelum dan sesudah intervensi (Tabel II)

Pada medication reminder chart skor MMAS-8 sebelum dan sesudah intervensi adalah 3,20 menjadi 6,10 , ada peningkatan skor MMAS-8 sebesar 2,9. Terdapat perbedaan yang bermakna pada penggunaan medication reminder chart terhadap peningkatan kepatuhan sebelum dan sesudah intervensi dengan nilai $p<0,05$ $(p=0,00)$ setelah di uji dengan uji Wilcoxon, adanya perbedaan bermakna pada nilai $p$ medication reminder chart, maka dapat disimpulkan bahwa pemberian medication reminder chart dapat meningkatkan kepatuhan 
secara statistik pada pasien geriatri dengan hipertensi (tabel II).

Pada penelitian ini selain mengukur kepatuhan pasien dengan menggunakan MMAS-8 digunakan juga pill count. penentuan kepatuhan pasien dengan cara menghitung sisa obat dari pasien atau dengan "pill count" akan didapatkan persentase kepatuhan dari pasien. Metode pill count ini dilakukan dengan menghitung sisa obat yang didapatkan pasien selama terapi pada periode waktu tertentu. Kepatuhan dinyatakan dengan $\geq 80 \%$ dan tidak patuh $<80 \%$ (Indrasanto, 2006).

Berdasarkan hasil penelitian maka didapatkan penghitungan sisa obat dari pasien (Tabel III). Dalam hal ini, perhitungan pill count dilakukan pada saat pasien kembali datang melakukan kontrol setelah 1 bulan diberikan intervensi berupa pill box maupun medication reminder chart. Dari hasil penelitian sebesar 70\% (35 dari 50 pasien) mempunyai kepatuhan 100\% terhadap pengobatan yang didapatkannya (Tabel III. Sedangkan 36\% (18 dari 50 pasien) mempunyai kepatuhan $100 \%$ terhadap pengobatan yang dilakukan pada kelompok medication reminder chart. Dari hasil uji MannWhitney Test di peroleh nilai $\mathrm{p}<0,05$ maka terdapat perbedaan signifikan secara statistik antara kelompok pill box dengan medication reminder chart terhadap tingkat kepatuhan pasien.

Dari hasil uji statistik dengan nilai $P=0,001$ maka dapat dikatakan secara statistik pill box lebih efektif daripada medication reminder chart dalam meningkatkan kepatuhan terhadap pasien geriatri dengan hipertensi di Kota Batam

Pengaruh Pill box dan Medication reminder chart terhadap Outcome Klinik pada Pasien Geriatri

Tekanan darah dimonitor untuk beberapa alasan, yaitu untuk melihat respon awal terapi, monitoring perubahan tekanan darah jangka panjang dan membuat penilaian tentang kepatuhan pasien terhadap terapinya (Hayen et al., 2010). Intervensi yang dilakukan oleh farmasis dalam memperbaiki outcome klinik pasien hipertensi, dalam hal ini tercapainya kontrol tekanan darah yang baik (Chabot et al., 2003; Rose et al., 2011)
Nilai rata-rata tekanan darah sistolik Pill box pada saat sebelum intervensi adalah 159 $\mathrm{mmHg}$ dan setelah intervensi adalah 149 $\mathrm{mmHg}$, sehingga terdapat penurunan tekanan darah sebesar $10 \mathrm{mmHg}$, dimana didapatkan nilai $P=0,000$ yang diuji dengan uji Wilcoxon dengan CI 95\% maka dapat dikatakan bahwa secara statistik pemberian Pill box dapat menurunkan tekanan darah sistolik pada pasien geriatri dengan hipertensi.

Penelitian ini sejalan dengan penelitian Porter (2014) dimana pada penelitian yang dilakukan oleh Porter diikuti oleh 60 subyek akan tetapi hanya 50 yang dapat menyelesaikan penelitian hingga akhir, hasil penelitian tersebut menunjukkan meskipun secara statistik tidak dapat menurunkan tekanan darah sistolik $(P=0,438)$ akan tetapi secara klinis dapat menurunkan tekanan darah sistolik sebesar 10 $\mathrm{mmHg}$ serta peningkatan jumlah pasien hipertensi yang mencapai goal tekanan darah sistolik.

Nilai rata-rata tekanan darah sistolik medication reminder chart pada saat sebelum intervensi adalah $158,30 \mathrm{mmHg}$ dan setelah intervensi adalah $158,50 \mathrm{mmHg}$, terdapat peningkatan tekanan darah sebesar $-0,2 \mathrm{mmHg}$, dimana didapatkan nilai $P=0,864$ (tabel II) yang diuji dengan uji Wilcoxon dengan CI 95\% maka dapat dikatakan bahwa secara statistik pemberian medication reminder chart tidak dapat menurunkan atau medication reminder chart kurang memberikan efek terhadap penurunan tekanan darah sistolik pada pasien geriatri dengan hipertensi.

Nilai rata-rata tekanan darah diastolik pill box pada saat sebelum intervensi adalah 94,80 $\mathrm{mmHg}$ dan setelah intervensi adalah 89,80 $\mathrm{mmHg}$, sehingga terdapat penurunan tekanan darah sebesar $5 \mathrm{mmHg}$, dimana didapatkan nilai $\mathrm{p}=0,002$ yang diuji dengan uji Wilcoxon dengan CI 95\% maka dapat dikatakan bahwa secara statistik pemberian Pill box dapat menurunkan tekanan darah diastolik pada pasien geriatri dengan hipertensi.

Nilai rata-rata tekanan darah diastolik medication reminder chart pada saat sebelum intervensi adalah 94,20 $\mathrm{mmHg}$ dan setelah intervensi adalah 94,40 $\mathrm{mmHg}$, sehingga 
terdapat peningkatan tekanan darah sebesar -2 $\mathrm{mmHg}$, dimana didapatkan nilai $P=0,870$ yang diuji dengan uji Wilcoxon dengan CI 95\% maka dapat dikatakan bahwa secara statistik pemberian medication reminder chart tidak dapat menurunkan tekanan darah diastolik pada pasien geriatri dengan hipertensi (Tabel II)

Perbandingan Efektifitas Pemberian Pill box dan Mediaction Chart terhadap Peningkatan Kepatuhan, Tekanan Darah Sistolik dan Diastolik

Berdasarkan analisis rerata nilai peningkatan skor MMAS-8 setelah dilakukan intervensi menggunakan uji statistik MannWhitney Test tidak berpasangan yang terdistribusi secara tidak normal setelah di uji normalitas Kolmogrov Smirnov maka didapatkan nilai $P=0,008$. Berdasarkan nilai $P<0,05$ menunjukkan bahwa terjadi perbedaan yang bermakna dimana intervensi Pill box lebih efektif dibandingkan dengan Medication reminder chart dalam meningkatkan kepatuhan pasien geriatri dengan hipertensi dalam menjalankan terapi pengobatannya.

Rerata penurunan nilai tekanan darah sistolik dan diastolik berbeda bermakna terhadap pemberian pill box dan medication reminder chart dengan nilai $P=0,006$ dan $P=0,015$. Nilai $P<0,05$ menunjukkan bahwa terdapat perbedaan bermakna antara intervensi Pill box dengan Medication reminder chart pada pasien geriatri dengan hipertensi.

Berdasarkan tabel IV secara keseluruhan dapat dikatakan bahwa intervensi yang dilakukan dengan memberikan pill box lebih efektif dibandingan pemberian medication reminder chart dalam meningkatkan kepatuhan dan menurunkan tekanan darah sistolik maupun tekanan darah diastolik.

Tidak terjadinya penurunan tekanan darah kelompok medication reminder chart pada penelitian ini dapat disebabkan beberapa faktor, berdasarkan hasil wawancara setelah intervensi dilakukan, beberapa faktor yang menyebabkan pill box dapat meningkatkan kepatuhan lebih efektif dibandingakan medication reminder chart adalah karena penggunaan pill box lebih membantu pasien lansia dibandingkan penggunaan medication reminder chart, hal ini dilihat dari subyek penelitian adalah pasien geriatri yang memiliki imobilitas terbatas dan daya ingat yang menurun sehingga penggunaan pill box dianggap sangat membantu pasien dalam mengatur obatnya dalam menjalankan terapi dibandingkan dengan medication reminder chart. Untuk pasien geriatri penggunaan medication reminder chart dianggap kurang membantu mereka dalam menjalankan terapinya, disebabkan karena mayoritas dari subyek penelitian beranggapan bahwa memberikan tanda pada mediction chart setelah mereka meminum obatnya cukup merepotkan subyek penelitian, karena harus mencari pulpen dan risiko medication reminder chart tercecer, hilang atau basah. Kedua mayoritas subyek penelitian memiliki pendidikan rendah sehingga mereka tidak kurang mampu membaca kolom mana yang harus ditandai utuk obat yang telah di minum. Berbeda dengan pill box, pill box pada penelitian ini dirancang untuk pengobatan selama seminggu, pengobatan harian di buat sederhana dengan menggunakan klip plastik dimana klip plastik tersebut telah diberi warna untuk setiap kali minum obat, warna kuning untuk pagi hari, merah untuk siang hari dan hijau untuk malam hari, adanya penandaan warna akan membantu mengurangi terjadinya human eror dimana pasien salah mengambil obatnya.

\section{KETERBATASAN PENELITIAN}

Proses penelitian telah diupayakan untuk mencapai hasil yang terbaik, namun begitu masih terdapat keterbatasan antara lain : Subyek penelitian merupakan pasien rawat jalan, banyak faktor yang berpengaruh pada penelitian yang tidak dapat dikendalikan secara maksimal. Pengambilan data berupa tekanan darah mungkin dipengaruhi oleh tingkat stres, pola makan, aktivitas, dan ritme sirkadian faktor lain yang dapat berbeda saat pengambilan data pretest dan posttest dan yang sulit dikendalikan. Serta jumlah sampel yang terbatas dan waktu penelitian yang singkat belum mampu mengambarkan pengaruh kepatuhan dengan kontrol tekanan darah dengan baik. 


\section{KESIMPULAN}

Pemberian pill box dapat meningkatkan kepatuhan, serta dapat menurunkan tekanan darah sistolik dan tekanan darah diastolik pada pasien geriatri dengan hipertensi di Kota Batam. Pemberian medication reminder chart dapat meningkatkan kepatuhan, akan tetapi belum dapat menurunkan tekanan darah sistolik dan tekanan darah diastolik pada pasien geriatri dengan hipertensi di Kota Batam. Pill box lebih baik dibandingkan dengan medication reminder chart dalam meningkatkan kepatuhan dan penurunan tekanan darah sistolik dan diastolik pada pasien geriatri dengan hipertensi di Kota Batam.

\section{DAFTAR PUSTAKA}

Anggraini, D.A., Waren, A. Situmorang, E. Asputra, H. Siahaan, S.S. 2009. FaktorFaktor yang Berhubungan dengan Kejadian Hipertensi pada Pasien yang Berobat di Poliklinik Dewasa Puskesmas Bangkinang Periode Januari Sampai Juni 2008. Fakultas Kedokteran. Universitas Riau, Pekanbaru. $1-41$

Budiharto, 1999, Pendidikan Kesehatan dan Ilmu Perilaku Kesehatan, Rineka Cipta, Jakarta.

Chabot, I., Moisan, J.P., and Milot, A. 2003, Pharmacist Intervention Program for Control of Hypertension. The Annals of Pharmacotherapy 37(9), 1186-1193.

Conn, V.S., Hafdahl, A.R., Cooper, P.S., Ruppar, T.M., Mehr, D.R., Russel, C.L. 2009. Interventions to Improve Medication Adherence Among OlderAdults: MetaAnalysis of Adherence Outcomes Among Randomized Controlled Trials. 49 (4), p. 447-462.

Dulmen, S.V., Sluijs, E., Dijk, L.V., Ridder, D., Heerdink, R., \& Bensing, J., 2007, Patient adherence to medical treatment, BMCHealth Services Research, 7: 55.

Fung, V., Huang, J., Brand, R., Newhouse, J.P., and Hsu, J. 2007, Hypertension treatment in a medicare population : Adherence and Systolic Blood Pressure Control Control Therapeutics, 29(5), 972-984.
Gabriel, M., Gagnon, J.P., and Bryan, C.K.,1977. Improved Patient Compliance through Use of a Daily Drug Reminder Chart, AJPH, 67 , p 967-968.

Hayen, A., Bell, K., Glasziou, P., Neal, B and Irwig L, 2010. Monitoring Adherence to Medication by Measuring Change in Blood Pressure. Journal of The American Heart Association, 56: 612-616.

Hutapea, R. 2005. Sehat dan Ceria di Usia Senja. Penerbit Rineka Cipta. Jakarta.

Indrasanto, Doti. 2006. Glosarium Data dan Informasi Kesehatan. Departemen Kesehatan RI. Jakarta.

Kim, J.MD., Shin, W.MD, 2014. How to Do Random Allocation (Randomization), Department of Orthopedic Surgery, Seoul Sacred Heart General Hospital, Seoul, Korea.

Kumar, V. Abbas, A.K., Fausto, N. 2005. Pathologic basic of disease.7th ed. Philadelphia: Elsavier Saunders (5): 270.

Laubscher, Tessa., Charity, E.DB, PhD., Jeff, Taylor, PhD., and Shari, McKay. M.A., 2009. Collaboration between family physicians and community pharmacists to enhance adherence to chronic medications. Can Fam Physician (55): e69-75

Lee, J.K., Grace, K.A., Foster, T.G., Crawley, M.J., Erowele, G.I., Sun, H.J., Turner, P.T., Sullenberger, L.E., and Taylor, A.J., 2007. How should we measure medication adherence in clinical trials and practice?. Therapeutics and Clinical risk Management, 3, 4, 685-690

Morisky, D.E, Ang. A., Krousel-Wood M, Ward H., 2008 Predictive validity ofamedication adherence measure for hypertension control. J ClinHypertensi,10:348-354.

Ogedegbe, G., Tobin, J.N., Fernandez, S., Gerin, W., Diaz-gloster, M., Cassells, A., Khalida, C., Pickering, T., Schoenthaler, A., \& Ravenell, J. 2009, Counseling African Americans To Control Hypertension (CCATCH) trial: a Multi-level intervention to improve blood pressure control in hypertension blacks. Journal of The American Heart Association. 2:249-256 
Petersen, M.L., Wang, Y., Laan, M.J., Guzman, D., Riley, E., dan Bangsberg, D.R., 2007. Pillbox Organizer Are Associated with Improved Adherence to HIV Antiretroviral Therapy and Viral Suppression: A Marginal Structural Model Analysis. HIV/AIDS CID, 45 : 908-915.

Porter, CB., JA. 2014. Development and evaluation of the kansas city cardomyopathy questionnaire: a new health status measure for heart failure.J Am Coll Cardiol. 35:1245-1255.

Rose, A., Glicman, M.E., Manze, M., Orner, M.B., Berlowitz, D., and Kressin, N.R., 2011. Effect of Daily Adherence to
Antihypertensive Medication on TimeVarying Blood Pressure Control. Journal Clinical Hypertension, 13 (6).

Sigalingging, G. 2011.Karakteristik Penderita Hipertensi di Rumah Sakit Umum Herna Medan Tahun 2011. Dosen Fakultas Ilmu Keperawatan. Universitas Darma Agung. Medan : 1-6.

United Nations, 2007. The Ageing of theWorld's population.

http://www.un.org/esa/socdev/ageing/po pageing.html. (diakses tanggal 30/8/2015).

Watson, Roger. 2003. Perawatan Pada Lanjut Usia. Jakarta: EGC 